\title{
FROM TRADITIONAL BUSINESS TO SOCIAL ONE: NEW POSSIBILITIES FOR ENTREPRENEURS IN RURAL AREAS
}

\begin{abstract}
Jolita GREBLIKAITE, Institute of Business and Rural Development Management, Faculty of Economics and Management, Aleksandras Stulginskis University, Universiteto str 10, Akademija, Kauno raj., Lithuania; jolita19@gmail.com (corresponding author)

Neringa GERULAITIENE, Kaunas University of Technology, K. Donelaicio str. 73, Kaunas, Lithuania; neringa.gerulaitiene@ktu.lt

Wlodzimierz SROKA, Department of Management, University of Dąbrowa Górnicza, 41-300 Dabrowa Gornicza, ul. Cieplaka 1c, Poland; wsroka@wsb.edu.pl

In many EU countries economic and social development stagnates. The reasons are various and depends on the country. Some countries are still leaders (Germany, Great Britain, France), but depending on political events and complicated issues in each of them common EU internal market is kept as rather passive and not expanding in terms of consumption and investments. Especially it is related to countries suffering their internal business problems. The research problem of this paper is related to the issues how to provide some innovative solutions to traditional enterprises in Lithuania and Poland for their prosperous development. The aim of the paper is to analyse the situation and problems of traditional business in rural areas of Lithuania and Poland and propose development possibilities applying social initiatives and becoming social enterprises. The research object of the paper is traditional and social enterprises in rural areas. The research discloses that in Lithuania and Poland the situation in rural areas has a lot of similarities in terms of development and problems. Social entrepreneurship in both countries is kept as possibility but still problems and specificity exist in the countries.
\end{abstract}

Keywords: rural areas, traditional business, social business.

\section{INTRODUCTION}

Lithuania and Poland are neighbourhood countries. From economy viewpoint trade policy, business relations between two countries are very important. The research in this paper is oriented to business issues in rural areas of both countries. It is valuable and significant for better acquaintance of situation of both countries, their problems and possibilities of business development and improved business relations among enterprises of both countries. The aim of the paper is to analyse the situation and problems of traditional business in rural areas of Lithuania and Poland and propose development possibilities applying social initiatives and becoming social enterprises. The research object of the paper is traditional and social enterprises in rural areas. The main tasks of the research made in the article are: to analyse the situation of traditional business in Lithuania and Poland focusing on rural areas; to present and explain possibilities and problems of diversified activity becoming social entrepreneurs; to discuss the development of social enterprises in Lithuania and Poland. The research methods of the paper are scientific literature analysis, comparative analysis, statistical data analysis, situation analysis. The paper is kept as exploratory.

\section{TRADITIONAL BUSINESS IN RURAL AREAS IN LITHUANIA AND POLAND: SITUATION ANALYSIS}

According to the document of Lithuanian Rural Development (2005), rural areas are defined as all territories, which do not fall under the categories of urban territories or urban type settlements. In the final report of European Commission (2008) it is distinguished that rural area is a territory dominated by the natural environment and depopulated density.

Rural areas form significant part of Lithuanian territory and make contribution to economic and social development. Farmland comprises $60 \%$ in Lithuania and $42 \%$ of population lives in rural areas (European Commission, 2016). The main characteristics of rural areas in Lithuania are: emigration of young people, decreasing birth rate, aging of population, people are less prepared for undertaking various business activities than people in city areas, poor development of business, lacking alternative employment, lack of human capital (European Commission, 2008).

Copyright (C) 2017 The Authors. Published by Aleksandras Stulginskis University. This is an open-access article distributed under the terms of the Creative Commons Attribution License (CC-BY 4.0), which permits unrestricted use, distribution, and reproduction in any medium, provided the original author and source are credited. 
Agriculture, hunting, forestry and fisheries are the part of economic sector in rural areas in Lithuania. Another group of population is working in industry and construction, services such as education, health care, social work, tourism and other activities (Stakeniene, n.d). Lithuania has good conditions to develop the agriculture and rural settlements: climatic conditions are supportive of dairy and meat farming, stock-breeding and growing cereals, vegetables, potatoes, fruits, sugar beets, flax and other plants; sufficient agricultural resources and their natural productivity (Stanaitis, 2004). On the other hand, there are a low competitiveness of small and medium-sized farms, an aging farming community: $35 \%$ of farmers are 65-years-old or more (EU-average of 30\%) (European Commission, 2016).

Rural tourism is also popular traditional rural business (Stakeniene, n.d.). Rural tourism contain excursions to the country-side or the leisure time spent in a farmstead and other services related to the culture, traditions, history and natural environment (Buciene and Merkiene, 2014). Tourism creates new work places, develops local culture in rural areas, encourages rural areas regeneration and development of economy, increases quality of life for rural communities and visitors (Snieška, Barkauskienè etal., 2014).

Since Lithuania has joined the EU in 2004, population of rural areas starting to receive significant financial aid from the European budget. In the period to 2020, the Common Agriculture Policy (CAP) will invest around EUR 4.7 billion in Lithuania's farming sector and rural areas (European Commission, 2016). Key political priorities in rural areas have been defined at European level such as: jobs and growth, sustainability, modernisation, innovation and quality (European Commission, 2016).

Nowadays rural tourism is growing, but there is still a lack of jobs in rural areas. In the sector of agriculture, hunting, forestry and fisheries worked $23.2 \%$ of rural community in 2016 . The number of small and medium enterprises raised $39.6 \%$ from 2012 to 2016. Totally 13900 small and medium enterprises were in rural areas in Lithuania in 2016 (80\% of them are micro enterprises) (Lithuanian Institute of Agrarian Economics, 2017). Rural business faces various problems in Lithuania as lack of finances, innovations, and modern technologies, small internal market, unqualified labour force, etc. Businesses are more developed in cities than in rural areas, more investments, human resources are allocated in cities (European Commission, 2015).

The situation of business in rural areas in Poland is strongly diversified. There are regions characterised by dynamic development, where people successfully utilize social and economic potential and various forms of business support. But there are also areas of stagnation where traditional agriculture is still the main economic activity. This is probably the result of a combination of factors, including lack of knowledge and experience, insufficient information, lack of investment and cooperation opportunities, excessive administrative procedures, underdevelopment of business support institutions. Historical conditions play a significant role here (e.g. in western Poland, which was under German domination for several centuries, the situation is much better than in the so-called eastern wall, or Podkarpacie).

According to Kamińska (2011), in 2009 the economic activity index in Poland amounted to 105. It was, however, strongly diversified, with urban areas at 125 and in rural areas - 64. The overall picture of this indicator in spatial terms indicates that its value increases when moving from east to west. High economic activity is also a feature of municipalities located close to large cities and attractive tourist areas. This is determined by the location pension in relation to important transport routes, the proximity of large markets, the elevated level of development of technical and social infrastructure and the resources of human capital. The lowest level of this index is found in the Lubelszczyzna and in many communes of the Podkarpackie, Podlaskie and the northern part of the Warmia-Mazury province. One may mention several reasons of this state, e.g. low level of education, excessive participation of employees in agriculture (though this number diminishes every year), underdevelopment of financial infrastructure and institutions supporting entrepreneurship.

\section{POSSIBILITIES AND PROBLEMS OF BECOMING SOCIAL ENTREPRENEURS}

A substantial proportion of social enterprises is in rural areas. Despite this fact that, rural social enterprise is underresearched (Munoz, 2011). To some it is strange as rural locations can offer a very good place for establishing and operating social enterprises (Steinerowski et al. 2008). Therefore, social enterprises could play a key role in enhancing sustainability of rural communities, for example they might be especially useful in providing local services in remote rural areas (Osborne, 1998). This is because people who live in remote areas display a greater propensity to engage in social rather than commercial entrepreneurship compared with those living in urban areas. In addition, they draw upon traditional rural strengths, including strong mutual knowledge, sense of community and social cohesion. This is also associated with the fact that social networks are denser in rural areas than urban ones. It causes an important level of trust and active civic participation which are regarded as the key components of the social capital associated with social enterprise development. The existence of collective activity, co-dependence, as well as reciprocity are factors which cause that rural areas to seem to be a very good place for social enterprises (Steinerowski, Steinerowska-Streb, 2012).

Rural communities are subject to the intensive transformation process that began in Poland in 1989. A new opportunity for the rural inhabitants came with the Polish accession to the European Union. Not only the Polish agriculture, but also Polish rural areas gained widespread financial ability to support development processes, mainly under the Common Agricultural and Rural Development Policy (Michalewska-Pawlak, 2010). In other words, Polish accession to the European Union improved the economic situation of the rural inhabitants (Michalewska-Pawlak, 2012).

In Lithuania special support now is focused for social entrepreneurship in rural areas involving local action groups. New rules for the calls were released (NMA, 2017; see www.nma.lt). It provides new possibilities for rural areas to develop social enterprises, thinking about reconstructing existing activities to socially oriented and creating various products and different added value for actors in rural areas. 
EU funds support different sectors of economy in rural areas, e.g. agritourism. One should add that the economic need felt by inhabitants of rural areas also stimulates the development of agritourism. The activation and development of the countryside and agriculture owing to agritourism are perceived mainly as resulting from better opportunities of earning an off-farm income. Agritourism as a form of business activity attracts farm operators because of economic considerations (an additional source of income), organizational and legal reasons (development of agritourism is encouraged by agritourism associations and agricultural advisory centres as well as favourable legal solutions), social (town residents feel a growing need to spend free time in safe and socially accessible rural environment) and ecological aspects (more and more tourists desire contact with clean and healthy nature in rural areas) (Sikora, 2012). All tourism programmes are important both for tourists and inhabitants of a given area. They provide jobs, additional sources of income and improved professional skills (Marks-Bielska et al. 2014). Given the facts presented (and especially advantages associated with this form of activity), no wonder that agritourism offer great opportunities for social entrepreneurship.

Since the adoption of the Law in 2004, the number of registered social enterprises in Lithuania increased five times and the number of their supported employees - seven times (see Figure 5). Over 10-year period state subsidies increased more than 20 times, from 0.57 million Eur in 2004 to more than 11.58 million Eur planned in 2014. Since 2008 large part of these subsidies are allocated from the ESF funds. It is forecasted that in 3 years number of social enterprises (as per Law on Social Enterprises) will not increase significantly (5-6 start-ups per year). However, number of the disabled employees could reach 7000. Thus, demand for state subsidies could reach about $€ 18.83$ million EUR or around 1.5 times more than in 2014 and is likely to constantly grow further.

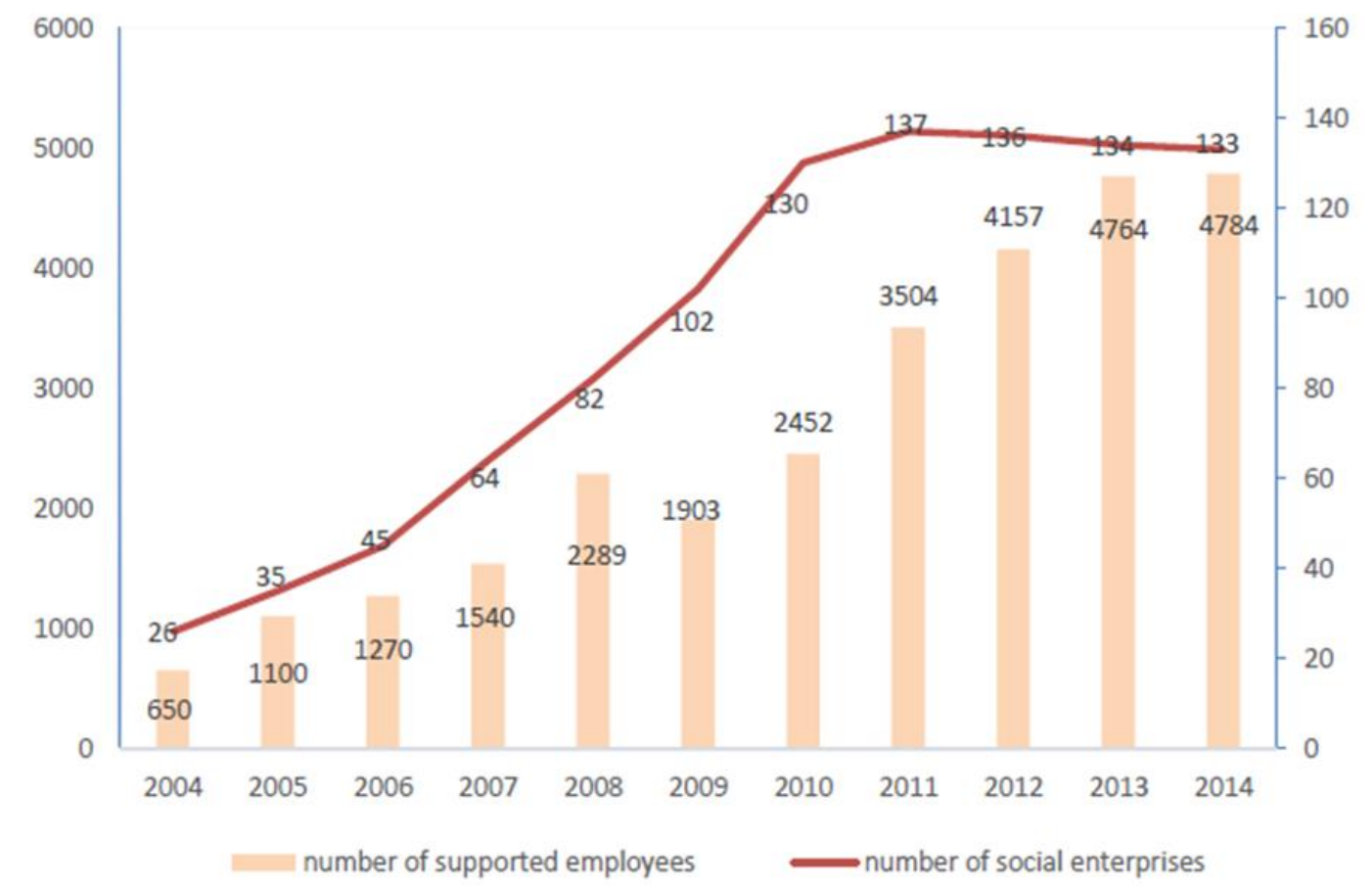

. Source: Created by the authors according to Lithuanian Labour Exchange

Figure 1. Social enterprises distribution by manufacturing activities

It should be noted, however, that at present one observes the increase in the social and economic activity of the inhabitants in rural areas in Poland. It also relates to the development of non-agricultural business entities. As a result, the diversity and level of multifunctionality of rural areas increases, the structure of household incomes changes and new jobs are created (Kłodziński, 2010). As Bański (2008, pp. 129-131) notes, entrepreneurship in the countryside has a significant impact on the general development of the regions, including the improvement of the quality of life in rural areas. Given these facts, the key problem to solve is then defining the determinants of development of rural entrepreneurship. In terms of rural development, five factors play a key role (Bański 2015 b):

- institutional environment of rural entrepreneurship, i.e. entities supporting the economic activity in rural areas: training, advisory, information, financial, research and development and self-government institutions;

- financial support, i.e. own and foreign sources of business activity financing;

- regulatory environment - various legal regulations on entrepreneurship (obligatory social insurances, taxes, environmental protection, etc.);

- $\quad$ cooperation - the ability to create synergies and ties to achieve common benefits and solve problems;

- competitiveness - potential of the company, including resources, skills and capabilities that provide an advantage over other players in the same sector.

According to Bański (2015 a), business environment institutions have great opportunities to support entrepreneurs in rural areas and to shape business, but they are not currently properly used. Only 20-25\% of the companies in the 
countryside use their services. In additional, entrepreneurs have very limited knowledge on the institutions that can support their business, and that is why relatively few use their services or various forms of cooperation. Agricultural advisory centers belong to the best-known institutions supporting rural businesses.

Among barriers hindering cooperation with business environment institutions, entrepreneurs most often mention: lack of information about the services offered by such institutions, insufficient experience in cooperation and lack of financial resources. Representatives of the business environment add to these barriers also the "mentality" of entrepreneurs, understood as attachment to old principles, distrust to innovative solutions, lack of faith in success, etc. Improvement of efficiency requires above all the promotion of services offered and elimination of procedural barriers. Therefore, it is important to emphasize the need to develop the right form of information about the business environment and to reach out to companies in the countryside.

\section{DEVELOPING SOCIAL ENTERPRISES IN RURAL AREAS OF LITHUANIA AND POLAND}

Rural-based activities are the result of regional and cohesion policy, which in turn links the concept of durable and sustainable development (Wilkin, 2013). The concept of sustainable development is the cornerstone of EU policy, and its implementation in relation to rural development requires the involvement and cooperation of many entities.

In EU countries, local development is coherent with the objectives and priorities set by the European Union. They define the general direction of development implemented in regional policy. Rural areas are important part of EU policy. Actions addressed to European rural communities reflect the importance of rural areas for global development. Almost half of Europe's territory is rural, which is home to around $20 \%$ of our continent's population. The EU co-finances the development of these areas by means of various programs, in which Poland also takes an active part. One should add that from the beginning of Polish membership in European Union, the development of rural areas relates to EU policy. One of the most important EU policy instruments stimulating rural development is the Rural Development Program (RDP), for the years 2014-2020.

The change of situation will be after year 2020 than support for rural development will be reduced from EU funds. Businessmen and citizens of Poland and Lithuania must use all the existing possibilities for developing traditional business in rural areas. For example, in Lithuania Agency for Research Innovation and Technologies (MITA) provides different possibilities how to improve competence of employees in various stages, for example, how to commercialise products, apply scientific research in activity of enterprises etc. Using these possibilities enterprises can generate innovative ideas, get appropriate knowledge and experience how to implement new technological and managerial solutions, for example, establish social enterprise.

An example of a tri-sector approach that supports development of rural areas are, inter alia, Partnership Groups (PG) for sustainable development. They are formed because of agreement of three entities: non-governmental organizations, local governments and business partners who work together for the good of the region and ensure its sustainable development, using local economic, natural and cultural potential. They provide the foundation for entrepreneurship, exploit the potential of the community not only for economic and social development, but also to support vulnerable groups (Knapik, 2014).

It is necessary to emphasize that beside Partnership Groups, there is also National Network of Partnership Groups which supports PG and is primarily focused on promoting supraregional and transnational cooperation (Knapik, 2014). The link between GP and other approaches, such as Leader and Equal, is the tri-sector partnership whilst the issue which differentiates these forms of activity is their financing, i.e. PGs may - though not necessarily - use EU funds (Benedek et al. 2008).

Another approach to sustainable development and the use of local potential is the Leader program, which aims to tackle the unfavourable and crisis phenomena in rural areas. It may be regarded as a tool for social capital building, strengthening social bonds and stimulating civic participation. It insists on network management, partnerships with the environment and social understanding building, as well as the opportunities for participation of different actors. This program introduces a new quality leadership to local structures in accordance with the EU's good governance standards. It is based on the promotion of Local Action Groups - LAG (in Polish Lokalne grupy działania), linking together representatives of the public sector (local government, schools, government agencies and other public institutions), social organizations (mainly non-governmental organizations) and business entities (farmers, entrepreneurs and private companies). As of July 7, 2014, there were 335 LAGs operating in Poland, including the largest number in Małopolskie (39) and Mazowieckie (35) and the smallest in Lubuskie (10) and Opole (12) (Wykorzystanie...2015). On should add that LAGs initiate and stimulate entrepreneurial processes, utilize local potential and mobilize other market players (Knapik, 2014.) In Lithuania, LAGs are more and more active, especially because of additional government attention.

\section{CONCLUSIONS}

The economic sector in rural areas consist of agriculture, hunting, forestry and fisheries. Another group of population is working in industry and construction, services such as education, health care, social work, tourism and other activities. Nowadays rural business in Lithuania has many problems: depopulation, migration of young people, aging, lacking of human resources, business education and others. On the other hand, since 2004 Lithuania improved the situation in rural areas because of EU support. Latest rural development policy is tightly connected to social entrepreneurship and development of social enterprises in Lithuanian rural areas. In Poland traditional business has still more opportunities because of quite big market. Still the changes are happening and are generated because of innovative 
approaches of citizens to life quality, leisure, possibilities to know opportunities and real examples of different businesses and products. It is needed for both countries to use all the possibilities of business transformation from traditional to social especially in the areas where traditional business is stagnating.

\section{REFERENCES}

1. Bański, J. 2008. Wiejskie obszary sukcesu gospodarczego. Przegląd Geograficzny, Vol. 80(2), pp. 199-222. [In Polish]

2. Bański, J. 2015 a. Rola instytucji otoczenia biznesu w rozwoju przedsiębiorczości wiejskiej. Wieś i Rolnictwo, No. 2(167), pp. 139-149. [In Polish]

3. Bański, J. 2015 b. Uwarunkowania rozwoju przedsiębiorczości na wsi - wybrane zagadnienia. Roczniki Naukowe Ekonomii Rolnictwa i Rozwoju Obszarów Wiejskich, No.102(1), pp. 59-69. [In Polish]

4. Benedek, L. et al. 2008. Partnerstwo międzysektorowe. In: J. Tvrdoňová, U. Budzich-Szukała (Ed.). Jak animować partnerstwo na obszarach wiejskich? Poradnik praktyczny, FAOW, Warszawa, pp. 35-57 [In Polish]

5. Buciene, R., Merkiene, J. 2014. Sustainable Development and Rural Tourism in Lithuania. Revista de Ocio y Turismo, No.7, pp. 10-19.

6. European Commission. 2008. Poverty and Social Exclusion in Rural Areas: Final Report.

7. European Commission. 2015. Lietuvos kaimo plètros 2014-2020 programa. Available at https://ec.europa.eu/agriculture/sites/agriculture/files/rural-development-2014-2020/country-files/lt/fulltext_lt.pdf (Accesed on 27/10/2017) [In Lithuanian]

8. European Commission. 2016. The Common Agriculture Policy (CAP) in your Country. Available at https://ec.europa.eu/agriculture/sites/agriculture/files/cap-in-your-country/pdf/lt_en.pdf (Accesed on 26/10/2017)

9. Kamińska, W. 2011. Aktywność gospodarcza osób fizycznych na obszarach wiejskich w Polsce. In: W. Kamińska, K. Heffner (Ed.). Obszary wiejskie. Wielofunkcyjność, migracje, nowe wizje rozwoju, Studia KPZK PAN 133, Warszawa, pp.103-127. [In Polish]

10. Kłodziński, M. 2010. Mikroprzedsiębiorczość na obszarach wiejskich. Wieś i Rolnictwo, No. 2(147), pp. 20-34. [In Polish]

11. Knapik, W. 2014. Wybrane aspekty rozwoju polskich obszarów wiejskich na tle koncepcji zrównoważonego rozwoju oraz zakorzenionych rynków. Stowarzyszenie ekonomistów rolnictwa i agrobiznesu. Roczniki Naukowe, Vol. XVI(5), pp.109-113. [In Polish]

12. Lithuanian Institute of Agrarian Economics. 2005. Lithuanian Rural Development. Lithuanian Institute of Agrarian Economics, Vilnius.

13. Lithuanian Institute of Agrarian Economics. 2017. Agriculture and Food Sector in Lithuania: 2016. Lithuanian Institute of Agrarian Economics, Vilnius.

14. Marks-Bielska, R., Babuchowska, K., Lizińska, W. 2014. Agritourism as a form of business activity in rural areas. Acta Scientiarum Polonorum Oeconomia, No. 13(3), pp. 69-79.

15. Michalewska- Pawlak, M. 2010. Importance of the common agricultural policy of the European Union in the European rural areas development 2007-2013. Historical and Political Science Review, 1.

16. Michalewska-Pawlak, M. 2012. Social and cultural determinants of entrepreneurship development in rural areas in Poland. Available at https://zie.pg.edu.pl/documents/30328766/30681297/REME_1_\%281-2012\%29-Art5.pdf (Accessed on 4/11/2017).

17. Munoz, S.A. 2011. Towards a geographical research agenda for social enterprise. Area, Vol. 42(3), pp. 302-312.

18. Osborne, S.P. 1998. Voluntary organizations and innovation in public services. Routledge, London. https://doi.org/10.4324/9780203264829

19. Sikora, J. 2012. Agroturystyka. Przedsiębiorczość na obszarach wiejskich. C.H. Beck, Warszawa.

20. Snieška V., Barkauskienè K., Barkauskas V. 2014. The Impact of Economic Factors on the Development of Rural Tourism: Lithuanian Case. Procedia- Social and Behavioral Sciences, No. 156, pp. 280-285. https://doi.org/10.1016/j.sbspro.2014.11.189

21. Stakeniene J. n.d. Lithuania: Rural Development. Available at http://www.un.org/esa/agenda21/natlinfo/countr/lithuan/ruralDevelopment.pdf (Accesed on 25/10/2017)

22. Stanaitis S. 2004. Social, Economic and Demographic Changes of Rural Areas in Lithuania. Available at http://www.ibspan.waw.pl/erdn/images/ERDN-t2-part03.pdf (accesed on 26/10/2017)

23. Steinerowski, A., Jack, S., Farmer, J. 2008. Social entrepreneurship in a rural context: an over-ideological "state"? Journal of Rural Enterprise and Management, Vol. 4(1), pp. 20-39.

24. Steinerowski, A.A, Steinerowska-Streb, I. 2012. Can social enterprise contribute to creating sustainable rural communities? Using the lens of structuration theory to analyse the emergence of rural social enterprise. Local Economy, Vol. 27(2), pp. 167-182. https://doi.org/10.1177/0269094211429650

25. Wilkin J. 2013. Cele i zasady koordynacji polityk wspierajacych zrównoważony rozwój obszarów wiejskich. In: K. Heffner (Ed.). Rozwój obszarów wiejskich w Polsce a polityka spójności Unii Europejskiej: stare problemy i nowe wyzwania. PAN Komitet Przestrzennego Zagospodarowania Kraju, Studia T. CLIV, Warszawa, pp. 25-36. [In Polish]

26. Wykorzystanie środków publicznych na wdrażanie lokalnych strategii rozwoju w ramach programu rozwoju obszarów wiejskich 2007-2013. 2015. Raport Najwyższej Izby Kontroli, Warszawa. Available at https://www.nik.gov.pl/plik/id,8446,vp,10529.pdf (Accessed on 4/11/2017). 